\title{
The Role of R\&D in Shaping Public Sector Typologies: An European Perspective
}

\author{
Andrés Maroto ${ }^{1}$, Luis Rubalcaba ${ }^{2}$ \\ ${ }^{1}$ Economic Analysis: Economic Theory Department, Autonomous University of Madrid, Madrid, Spain \\ ${ }^{2}$ Applied Economics Department, University of Alcalá, Madrid, Spain \\ Email: andres.maroto@uam.es, luis.rubalcaba@uah.es
}

Received June 22, 2012; revised July 28, 2012; accepted August 13, 2012

\begin{abstract}
One of functions of the modern public states for improving dynamism in the economic system is the use of their support to cope with the market and systemic failures created in the innovation area: the R\&D promoted by public administrations can be considered a dimension, among others, of their performance in society. This paper explores the relationships between the R\&D promoted by public administrations and the different typologies of states from a European perspective. The results show some similarities between the public sectors in terms of general characteristics such as performance or stability and the most R\&D-oriented promoters. However, differences are found depending on indicators and types analyzed. The existence of large differences within each type of public sector is also confirmed. Results suggest the influence that pro-innovation profiles of public sectors might exert on general innovation system and performance patterns in EU countries.
\end{abstract}

Keywords: Public Sector; Typologies; R\&D; Innovation; Europe

\section{Introduction: R\&D in New Public Sector's Role}

Since mid-XX century public sectors have gaining importance in advanced economies developing social and economic functions in different ways, depending on historical traditions, administrative cultures, inspirations and development of welfare and growth. A third of the service employment created in Europe from the 1979 till 2007 has been generated in public sector. In Europe, many types of public states coexist with different sizes, socials roles, and performances. But, in the last 20 years all of them have something in common: they are seeking for modernization and performance. In this way some traditional functions are being be revised (e.g., better regulation actions to reduce enterprise burden and red tape, or measures to reduce interventionism in private markets) while others need to be reinforced (e.g., policies for growth, employment, productivity and innovation). One of key functions of the modernized public sectors for enforcing the economic system is the use of their support to cope with the market and systemic failures created in the innovation area: the $R \& D$ promoted by public administrations can be considered a dimension, among others, of their performance in society.

Public sector research and innovation plays a key role in technological change and consequently in economic growth. In recent years, a number of trends have emerged, heightening interest in the economic effects of public sector innovation and, specially, R\&D both in policy and academic circles. One of the key factors of the downturn of economic growth in the European Union in the aftermath of the Lisbon Council of 2000 is the structural nature of the EU's innovation systems and processes. If innovation is the process of generating and applying new ideas that raise living standards, create new growth industries, and improve the way institutions operate- then public sector will determine EU's success or failure in the innovation endeavor as much as the private sector, since the justification of public sector to face market and systemic failures in innovation are widely recognized (see, for example, Arrow, 1962 [1]; Griffith, 2000 [2]; OECD, 2002 [3]; Mowery and Sampat, 2002 [4]).

Although in that period labor apparent productivity of public administrations as such performed well in the EU (European Commission, 2005 [5]; Maroto and Rubalcaba, 2008 [6]), the question is if the current size, structure and functioning of European public sector is efficient enough to produce positive impacts throughout the whole economy. In terms of policy, the empirical results stresses that the EU's innovation system needs to be drastically reformed if the EU is to make a decisive shift towards realizing the broad features of which have been laid out in the Lisbon 2010 agenda. A structural reform and institu- 
tional change, and an emphasis on competitiveness that is based on science and on knowledge is a prerequisite for the Union to catch up with the United States and the dynamic Asian economies, and public sector has a key role in this process.

A recent research of the US Council on Competitiveness (2005) [7] explains the reasons why. Public sector sets the framework by which private entities innovate-as a regulator, an investor, a purchaser or a partner. Consider just a few public sector activities and their impact on putting new ideas into practice, such as research investment, education policy, intellectual property protection or infrastructure investment. Clearly, the capacity of the private sector to innovate relies heavily on public sector practices. Government also determines countries' innovation potential because the public sector accounts for a major portion of our society's activities ${ }^{1}$. Such an enormous swath of activity must be productive and efficient-it must be innovative-if EU countries are to prosper and compete in the global arena of 21st century.

Improving the performance of the public sector in terms of innovation is a goal that is high on the policy agenda in almost all European countries. Public policies play a key role in shaping competitiveness and growth in the economy. Due to the size of government activity, performance and efficiency in the public sector is an important determinant of aggregate economic performance at the national level. Secondly, the organization and functioning of governments affects the private sector via three main channels through which government action can have an impact: taxation (that distorts relative prices in the economy and thus influence economic incentives such as the willingness to work, to invest or to engage in entrepreneurial activities), public spending on areas such as education, $\mathrm{R} \& \mathrm{D}$ or infrastructure; and regulations (that limit the choices which individuals and enterprises can make), and the state of efficiency and modernization in the provision of public services (a high-performing administration will produce positive direct and indirect impacts in the economy as a whole).

Some of the public sector actions produce contradicttory effects in the economy, causing debate among researchers and policy-makers. For example, cross-country studies investigating the role of public capital in explaining productivity growth differentials provide no clear conclusions: while many of them find a positive impact, the effect is often not significant. For both education and $R \& D$, the case for the public sector involvement is often based on the existence of externalities. There is econometric evidence suggesting the R\&D performed by pub-

\footnotetext{
${ }^{1}$ In Sweden, which has the highest share of government employment in EU-15 in 2007, one out of three jobs is in the government sector. The Netherlands has the smallest share of government employment in 2007, one tenth of all jobs.
}

lic sector could have stronger impacts on economic performance than business R\&D (Griliches, 1992 [8]; Griffith, 2000 [2]). The extent to which public research can strengthen it depends also on the exploitation of the results in the business sector. Finally, some papers conclude that public R\&D has to some extent taken the place of private research rather than adding to it (David, Hall and Toole, 2000 [9]); however, most available studies do not find such substitution effects.

Furthermore, the public sector is not only a performer of R\&D, but also an important source of R\&D funding in the business sector. The gap in private research investment between the EU and the US ${ }^{2}$ has alarming conesquences for the long-term potential for innovation, growth and productivity performance. For this reason, the European Council in Barcelona 2000 decided to strive to increase gross expenditures on R\&D to 3 percent of GDP in the EU by 2010 with industry contributing two-thirds of the total amount of R\&D expenditures (European Commission, 2003). Public R\&D and programs for boosting innovation can be one of the most powerful instruments to overcome deficits and achieve competitive goals.

Public sector innovation, therefore, is directly related to economic prosperity and tightly linked to whether governments will meet their greatest national challenges in areas such as education or research and development. Following these ideas, the aim of this paper is twofold: to identify public sector typologies in Europe, upon which $R \& D$ can play a significant role, and to analyze if $R \& D$ performance in EU countries differs according to the structure, organization and typology of public administration. A final discussion is made exploring the influence that public innovation might exert on general performance patterns in EU public sectors.

\section{Public Sectors in Europe: Shaping Typologies and Impacts of Reforms in R\&D}

The modern public sector is a consequence of a long and even controversial process where different organizational models, sizes and profiles have been evolved. Public sector really has a great economic and social importance all over market economies, but even much more within the European Union. This fact becomes an economic achievement, and shows the EU trying to get the right balance between high social protection levels and income redistribution processes, what sometimes involve a certain trade-off between economic growth and income

\footnotetext{
${ }^{2}$ Expenditures on business sector R\&D as a percentage of GDP in the EU-15 (1.22 percent in 2007) lag significantly behind the US (1.93 percent in 2007) and Japan (2.68 percent in 2007) whereas there is virtually no gap in terms of public $R \& D$ expenditures (including the government and higher education sector ones).
} 
distribution. More recently, some other debates are in the center of discussion about the modern role of States; for example, the debate about complementarities or substitutions between public and private (crowding out effects included); the debate about the conflict between Welfare State and competitiveness or the debate on modernization and innovation of public sector.

The public sector in the economies of the advanced countries, and among them the European ones, fulfills nowadays one two-fold mission: it is creative and responsible of the institutional frame in which they operate the individuals and also an authority that take part actively in the economic processes correcting the results that would obtain the markets. Traditionally, it has been denominated "arrangement policy" to the first role, and "process policy" to the second one. In order to take care of both tasks, the public sector uses three generic instruments: regulations, public property, and state companies.

One of the main roles that the public sector takes at the present time is to develop all the activities that the Welfare State implies, which means the displacement of certain areas of the social conflict to the sphere of public action. In a strand of the literature, the performance of welfare states is linked to their institutions. A typology aims to explain the performance of national institutions for in the light of their key characteristics. One wellknown typology of institutions for social protection found in welfare states was developed by Esping-Andersen (1990) [10]. Before that, between 1960 and 1975 the three great models of European Keynesian Welfare State are based. Titmuss in 1974 [11] had laid the way towards the consideration of three models differentiated of social protection in advanced Capitalist states. Esping-Andersen retakes this proposal and builds a very influential three-poled typology. In his approach, the defining characteristic of welfare states is the generosity and accessibility of government programs designed to protect the citizenry against loss of income and poverty. Each type is different in terms of the regulation of labor markets (primary protection) and the level and scope of income guarantees (secondary protection). He distinguished, in particular, a Nordic or socialist model (with Sweden like paradigm), a Continental or Christian Democrat model (Germany) and an Anglo-Saxon or liberal model (United Kingdom). Eastern countries emerge as a separate type of welfare state (SCP/CERP, 2004 [12]), while some authors—such as Castles (1995) [13] or Rhodes (1997) [14] — describe an alternative model for Southern or Mediterranean countries.

Recent studies complement these typologies. Differences in administrative culture have a major impact both on fundamental choices concerning the structure of the public sector, and on the daily functioning of the government apparatus. Administrative culture forms part of a wider political and social culture. Hofstede's dimensions are probably the best-known categorization of administrative cultures (Hofstede, 1980 [15]), although other attempts have been made (Mamadouh, 1999 [16]). It is clearly no simple matter to group countries on the basis of their administrative culture. Loughlin (1994) [17] groups countries on the basis of broad philosophical and cultural traditions. He distinguishes an Anglo-Saxon (minimal state), a Germanic-organicist and a French Napoleonic state tradition. The Scandinavian type is a mix of the first two. Finally, Hooghe (2002) [18] used four dimensions developed by Page (1995) [19]—cohesion, autonomy from political control, caste-like character and non-permeability of external interest-to construct and index of "Weberian bureaucratic tradition" (strong, medium, weak), indicating to what degree a national administrative culture corresponds to the Weberian model (strong cohesion, large degree of autonomy from political control, strong caste-like character of the bureaucracy and low permeability of external interests).

Other studies have attempted to find a relationship between key demographic indicators and the institutions of welfare states. For example, Mellens (1999) [20] tried to relate birth rate, migration, family formation and the death rate to dominant socio-economic (level of income, educational attainment and health status of the population) and cultural treats of welfare states (gender equality, conservatism, individualism and post-modernism).

In summary, five groups of states can be distinguished in Europe according to all these characteristics (see Table 1). These country-clusters are the Scandinavian or Northern European, the Mediterranean or Southern European, the Continental or Western European, the AngloSaxon, and the Eastern European. Countries differ in terms of system characteristics, resource use and performance of the public sector (this public performance will be analyzed in detail in the next section). Nevertheless, it is possible to group European countries into these clusters that take account of each of those dimensions. These clusters are almost entirely consistent with generally accepted geographical/historical classifications of countries in Europe.

After the rapid expansion of the welfare state in the $50 \mathrm{~s}$ and 60 s, the public sector has been under considerable pressure in the past few decades. Declining public confidence in government institutions and growing demands on public finances have prompted governments to initiate measures to trim the public sector and make it more efficient and effective. Thus, after the great crisis in the 80s, a "new" state was being built during the 90s in the European Union. The objective of these new public administration management theories is to build a state that responds to the needs of its citizens, a democratic state where bureaucrats respond accountably to politi- 
Table 1. Typology of states in Europe.

\begin{tabular}{|c|c|c|c|c|c|}
\hline & $\begin{array}{l}\text { Scandinavian or } \\
\text { Northern European }\end{array}$ & $\begin{array}{l}\text { Mediterranean or } \\
\text { Southern European }\end{array}$ & $\begin{array}{l}\text { Continental or Western } \\
\text { European }\end{array}$ & Anglo-Saxon & Eastern European \\
\hline \multicolumn{6}{|c|}{ (a) According to general and socio economic characteristics } \\
\hline $\begin{array}{l}\text { Administrative } \\
\text { culture } 1\end{array}$ & Public interest & No clear & Rule of law & Public interest & Transition \\
\hline Insipration 6 & Socialism & Mix & Christian-democratic & Liberal & Post-communist \\
\hline State tradition 2 & $\begin{array}{l}\text { Mixture of Germanic } \\
\text { and French }\end{array}$ & French Napoleonic & Germanic or organicist & Anglo-Saxon & Communist \\
\hline $\begin{array}{c}\text { Type of } \\
\text { administration } 3\end{array}$ & Medium & medium-weak & medium-weak $^{*}$ & strong & Strong/weak \\
\hline Social 4 & $\begin{array}{l}\text { Medium ageing, high } \\
\text { crime rate }\end{array}$ & $\begin{array}{l}\text { High ageing, low } \\
\text { crime rate }\end{array}$ & $\begin{array}{l}\text { Medium ageing, } \\
\text { medium crime rate }\end{array}$ & $\begin{array}{l}\text { Low ageing, mixed } \\
\text { crime rate }\end{array}$ & $\begin{array}{l}\text { Low ageing, low } \\
\text { crime rate }\end{array}$ \\
\hline Economic 4 & $\begin{array}{l}\text { Average GDP per } \\
\text { capita, average } \\
\text { economic growth }\end{array}$ & $\begin{array}{l}\text { Low GDP per capita, } \\
\text { high economic growth }\end{array}$ & $\begin{array}{l}\text { Average GDP per } \\
\text { capita, low economic } \\
\text { growth }\end{array}$ & $\begin{array}{l}\text { High GDP per capita, } \\
\text { average economic } \\
\text { growth }\end{array}$ & $\begin{array}{l}\text { Low GDP per capita, } \\
\text { high economic growth }\end{array}$ \\
\hline
\end{tabular}

(b) According to public sector characteristics

\begin{tabular}{|c|c|c|c|c|c|}
\hline $\begin{array}{c}\text { General } \\
\text { characteristics }\end{array}$ & $\begin{array}{l}\text { High size, high quality } \\
\text { and high confidence }\end{array}$ & $\begin{array}{l}\text { Low size, low-medium } \\
\text { quality and low-medium } \\
\text { confidence }\end{array}$ & $\begin{array}{l}\text { Mixed size, medium } \\
\text { quality and } \\
\text { medium-high } \\
\text { confidence }\end{array}$ & $\begin{array}{l}\text { Medium size, } \\
\text { medium-high quality } \\
\text { and average } \\
\text { confidence }\end{array}$ & $\begin{array}{l}\text { Low-medium size, } \\
\text { low-medium quality } \\
\text { and low-medium } \\
\text { confidence }\end{array}$ \\
\hline $\begin{array}{c}\text { Public Service sector } \\
\text { characteristics } 4\end{array}$ & $\begin{array}{l}\text { Low private share, } \\
\text { public orientation, less } \\
\text { repressive, Beveridge } \\
\text { type, uniform education } \\
\text { and adversarial } \\
\text { criminal law system }\end{array}$ & $\begin{array}{l}\text { Low-medium } \\
\text { private share, average } \\
\text { repressive, Beveridge } \\
\text { type, medium } \\
\text { differentiated } \\
\text { education }\end{array}$ & $\begin{array}{l}\text { Medium private share, } \\
\text { public orientation, } \\
\text { less-average repressive, } \\
\text { Bismarck type, } \\
\text { differentiated education } \\
\text { and inquisitorial } \\
\text { law system }\end{array}$ & $\begin{array}{l}\text { Medium-high } \\
\text { private share, mixed } \\
\text { repressive, Beveridge } \\
\text { type, low-medium } \\
\text { differentiated } \\
\text { education }\end{array}$ & $\begin{array}{l}\text { Medium-high private } \\
\text { share, Bismarck } \\
\text { type, low-medium } \\
\text { differentiated } \\
\text { education }\end{array}$ \\
\hline PS performance 5 & $\begin{array}{l}\text { Medium-high } \\
\text { overall performance, } \\
\text { medium-high in } \\
\text { education, high in } \\
\text { health care, low } \\
\text { overall efficiency }\end{array}$ & $\begin{array}{c}\text { Low overall } \\
\text { performance, low in } \\
\text { education, medium-high } \\
\text { in health care, medium } \\
\text { overall efficiency }\end{array}$ & $\begin{array}{l}\text { Medium-high } \\
\text { overall performance, } \\
\text { medium-high in } \\
\text { education, high in } \\
\text { health care, low } \\
\text { overall efficiency }\end{array}$ & $\begin{array}{l}\text { Medium overall } \\
\text { performance, high in } \\
\text { education, medium-high } \\
\text { in health care, high } \\
\text { overall efficiency }\end{array}$ & $\begin{array}{l}\text { Medium-low overall } \\
\text { performance, } \\
\text { low-medium } \\
\text { in education, } \\
\text { ow-medium in health } \\
\text { care, medium-low } \\
\text { overall efficiency }\end{array}$ \\
\hline \multicolumn{6}{|c|}{ (c) According to social protection systems } \\
\hline Referring system 6 & $\begin{array}{l}\text { Redistribution } \\
\text { (equality) }\end{array}$ & Household attendance & Security & Attendance & $\begin{array}{c}\text { Transition towards } \\
\text { Civil Society }\end{array}$ \\
\hline $\begin{array}{l}\text { Secondary protection } \\
\text { (income guarantees) } 6\end{array}$ & $\begin{array}{c}\text { High social } \\
\text { expenditure level, } \\
\text { impositive financing } \\
\text { structure, universal } \\
\text { cover and social right } \\
\text { of citizens like criterion } \\
\text { for access }\end{array}$ & $\begin{array}{l}\text { Low social expenditure } \\
\text { level, impositive (taxes) } \\
\text { financing structure, } \\
\text { universal cover and } \\
\text { labour belonging like } \\
\text { criterion for access }\end{array}$ & $\begin{array}{c}\text { Average social } \\
\text { expenditure level, } \\
\text { contributively financing } \\
\text { structure, selective } \\
\text { cover and labour } \\
\text { belonging like criterion } \\
\text { for access }\end{array}$ & $\begin{array}{l}\text { Low expenditure level, } \\
\text { impositive (taxes) } \\
\text { financing structure, } \\
\text { selective cover and } \\
\text { need like criterion } \\
\text { for access }\end{array}$ & $\begin{array}{l}\text { Medium social } \\
\text { expenditure level, } \\
\text { impositive financing } \\
\text { structure, universal } \\
\text { cover and social right } \\
\text { of citizens like } \\
\text { criterion for access }\end{array}$ \\
\hline $\begin{array}{l}\text { Primary protection } \\
\text { (labour market } \\
\text { conditions) } 6\end{array}$ & $\begin{array}{c}\text { Average regulative } \\
\text { density, very centralized } \\
\text { and coordinated } \\
\text { collective agreements } \\
\text { structure, high cover } \\
\text { rate of these agreements, } \\
\text { very high union } \\
\text { affiliation density }\end{array}$ & $\begin{array}{c}\text { Highly regulated } \\
\text { system. Intermediate } \\
\text { systems for collective } \\
\text { agreements and } \\
\text { centralisation. Rigidity } \\
\text { and black labour. Low } \\
\text { union affiliation density }\end{array}$ & $\begin{array}{l}\text { High regulative density, } \\
\text { less centralized and by } \\
\text { sector collective } \\
\text { agreements structure, } \\
\text { very high cover rate } \\
\text { of these agreements, } \\
\text { average union } \\
\text { affiliation density }\end{array}$ & $\begin{array}{l}\text { Low regulative } \\
\text { density, decentralized } \\
\text { and by company } \\
\text { collective agreements } \\
\text { structure, average-high } \\
\text { cover rate of these } \\
\text { agreements, high union } \\
\text { affiliation density }\end{array}$ & $\begin{array}{l}\text { Transition systems from } \\
\text { fully regulated markets } \\
\text { towards liberal markers } \\
\text { Very centralized and } \\
\text { coordinated collective } \\
\text { agreements structure, } \\
\text { high cover rate of these } \\
\text { agreements, very high } \\
\text { union affiliation density }\end{array}$ \\
\hline
\end{tabular}

${ }^{1}$ Pollit and Bouckaert (2004); ${ }^{2}$ Louhglin (1994); ${ }^{3}$ Hooghe (2002); ${ }^{4}$ SCP/CERP (2004); ${ }^{5}$ Afonso et al. (2003); ${ }^{6}$ Maroto and Rubalcaba (2006); ${ }^{*}$ With the exception of France (strong). 
cians and politicians to voters (Hood, 1991 [21]; Frederickson, 1996 [22]). For that reason, there are essential moves: political reform to increase the legitimacy of governments; fiscal adjustment, privatization, deregulation to reduce the size of the state and improve its financial health; and administrative reform that, in addition to improving the financial situation of the state, will provide the means of good governance. Reform strategies adopted can be catalogued as a four-fold aim: maintain, modernize, marketize and minimize (Pollit and Bouckaert 2004 [23]) the public sector functioning and development.

Recent reforms in the public sector have often been carried out as a response to pressures to limit public spending, to strengthen economic performance or to keep up with the innovations introduced in the private sector, such as the introduction of information technologies. Country-specific forces are usually at the root of public sector reforms (Knox, 2002 [24]). In the international discourse concerning these reform developments there is a key interpretation arguing that, instead of a singular pattern of adaptation, there have been and there are several different paths in developed economies (Premfors, 1998 [25]; Torres and Pina, 2004 [26]; Capano, 2003 [27]).

Figure 1 summarizes three types of reforms handled to enhance efficiency in the public sector-management reforms, introduction of information technology, and outsourcing processes, use of knowledge-intensive services and public-private partnership (Maroto and Rubalcaba, 2006 [6]) - and their implications in R\&D activities; the role of pro-innovation actions leading to changes in the way $R \& D$ is promoted and managed. In this sense $\mathrm{R} \& \mathrm{D}$ is more than some "ad hoc" expenditure and serves

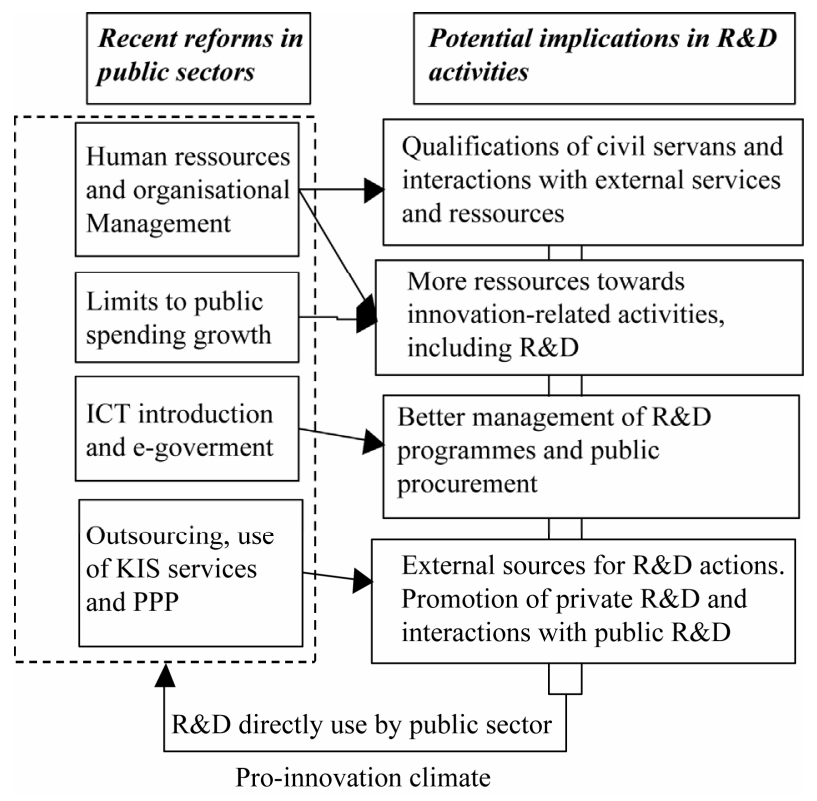

Figure 1. Public sector reforms and implications for R\&D. to promote a certain pro-innovation culture in public administrations. This culture dealing with $R \& D$ can be useful to develop pro-innovative activities such as the implementation of performance monitoring in educational reforms (Henry and Dickey, 1993 [28]) or may add new discussion elements suitable to be incorporated in organizational innovation studies (e.g., Pope, Robert, Bate and Le May, 2006 [29], Koch and Windrum, 2008 [30]) or innovation indicators in public administrations (e.g., Walker, Jeanes and Rowlands, 2002 [31]). The orientation towards more and better R\&D (public or business R\&D) may potentially reinforce the pro-innovative behaviors of administrations through the use of direct research (e.g., demanded by the public sector itself) and the pro-innovation climate (e.g., pro-innovation attitudes derived from the R\&D environment). The ex- tent and synergies between the $R \& D$ dimension in public sector and trends towards modernization will depend on many factors, among which the structure and type of public administration can act as a major one, as will be explored in next sections.

\section{Data and Introductory Results: Testing Inter-Type Differences}

Firstly, to test the role of typologies in reshaping public sector in Europe a database is prepared for the analysis. It is structured into two blocks: one referred to public sector and overall economic indicators (35 variables, see Appendix), and the other referred to R\&D indicators ${ }^{3} .25$ countries have been chosen clustered according the above mentioned five public sector typologies: Nordic or Northern (Denmark, Finland, Sweden, Norway and Iceland), Eastern (Czech Republic, Hungary, Poland and Slovak Republic), Central or Continental (Austria, Belgium, France, Germany, Luxembourg, Netherlands and Switzerland), Mediterranean or Southern (Greece, Italy, Portugal and Spain), and Anglo-Saxon (Ireland, United Kingdom, United States, Australia and Canada).

Secondly, the statistical significance of the differences between the five typologies was assessed using ANOVAs, after having checked that all variables met the assumption of parametric tests; when necessary, variables were log-transformed to achieve a normality and homogeneity of variances. As a working hypothesis, it confirms whether the typologies have different behaviors in respect to a series of features, on the basis of the existing differences stated in the previous sections (R\&D variables and general variables).

Table 2 shows the results for 34 variables on general socio-economic characteristics and performance of public sectors (26 countries). Just 5 (14.7 percent) are sig-

${ }^{3}$ Definition and description of variables (displayed at Tables 2 and 3) are available by the authors under demand. 
Table 2. ANOVA results for overall and public sector variables.

\begin{tabular}{|c|c|c|c|c|}
\hline & $\mathbf{N}$ & $\begin{array}{l}\text { Variation } \\
\text { coefficient }\end{array}$ & $\mathbf{F}$ & $\mathbf{p}$ \\
\hline Population & 26 & 1.86 & 0.96 & 0.4468 \\
\hline Population per m2 & 26 & 0.89 & $4.75^{\mathrm{a}}$ & $0.0068^{\mathrm{a}}$ \\
\hline Health Expenditure & 26 & 0.22 & 1.58 & 0.2149 \\
\hline Health Expenditure per capita & 26 & 0.41 & $6.03^{\mathrm{a}}$ & $0.0021^{\mathrm{a}}$ \\
\hline Life expectancy & 26 & 0.02 & $14.04^{\mathrm{c}}$ & $0.0000^{\mathrm{c}}$ \\
\hline GDP & 26 & 2.29 & 1.02 & 0.4164 \\
\hline GDP per capita & 26 & 0.31 & $7.34^{\mathrm{b}}$ & $0.0007^{\mathrm{b}}$ \\
\hline Ec Growth 94-04 & 26 & 0.41 & 1.85 & 0.1561 \\
\hline Ec Growth 03-04 & 26 & 0.40 & $4.80^{\mathrm{a}}$ & $0.0065^{\mathrm{a}}$ \\
\hline $\begin{array}{l}\text { Government Final Consumption } \\
\text { Expenditure Growth 2003-2004 }\end{array}$ & 26 & 1.14 & 3.10 & 0.0375 \\
\hline Net National Saving & 26 & 0.67 & 1.48 & 0.2495 \\
\hline Civilian Employment Growth 94-04 & 26 & 0.97 & 2.59 & 0.0658 \\
\hline Female Participation Rate & 26 & 0.13 & $5.56^{\mathrm{a}}$ & $0.0032^{\mathrm{a}}$ \\
\hline Part-time Employment Rate & 26 & 0.49 & $7.22^{\mathrm{b}}$ & $0.0008^{\mathrm{b}}$ \\
\hline Unemployment rate & 26 & 0.54 & 3.77 & 0.0183 \\
\hline PS revenue & 26 & 0.15 & $11.65^{\mathrm{c}}$ & $0.0000^{\mathrm{c}}$ \\
\hline PS expenditure & 26 & 0.14 & $6.01^{\mathrm{a}}$ & $0.0021^{\mathrm{a}}$ \\
\hline PS net saving & 26 & 7.91 & 3.40 & 0.0268 \\
\hline Tax receipts & 26 & 0.16 & $6.77^{\mathrm{b}}$ & $0.0011^{\mathrm{b}}$ \\
\hline Highest tax rate & 26 & 0.19 & 2.38 & 0.0839 \\
\hline Public employment & 26 & 0.37 & 1.35 & 0.2914 \\
\hline Inflation 03-04 & 26 & 0.52 & $7.33^{\mathrm{b}}$ & $0.0007^{\mathrm{b}}$ \\
\hline Expenditure on education & 26 & 0.16 & 3.34 & 0.0288 \\
\hline Expenditure on public education & 26 & 0.16 & $4.59^{\mathrm{a}}$ & $0.0080^{\mathrm{a}}$ \\
\hline Tertiary education Rate & 26 & 0.34 & $4.46^{\mathrm{a}}$ & $0.0091^{\mathrm{a}}$ \\
\hline Upper secondary or higher education Rate & 26 & 0.25 & $6.03^{\mathrm{a}}$ & $0.0021^{\mathrm{a}}$ \\
\hline PTVL & 26 & 0.26 & $13.44^{\mathrm{c}}$ & $0.0000^{\mathrm{c}}$ \\
\hline PTVH & 26 & 0.31 & $15.08^{\mathrm{c}}$ & $0.0000^{\mathrm{c}}$ \\
\hline PTVL growth 94-04 & 26 & 0.63 & $8.03^{b}$ & $0.0004^{\mathrm{b}}$ \\
\hline PTVH growth 94-04 & 26 & 0.54 & $5.13^{\mathrm{a}}$ & $0.0048^{\mathrm{a}}$ \\
\hline PSP & 26 & 0.14 & $8.21^{\mathrm{b}}$ & $0.0003^{\mathrm{b}}$ \\
\hline PSE & 26 & 0.29 & $23.23^{\mathrm{c}}$ & $0.0000^{\mathrm{c}}$ \\
\hline Quality of public administration & 22 & 0.26 & $8.86^{\mathrm{b}}$ & $0.0004^{\mathrm{b}}$ \\
\hline Political stability & 26 & 4.22 & 1.07 & 0.3920 \\
\hline Inequality & 25 & 0.17 & 3.46 & 0.0262 \\
\hline
\end{tabular}


nificant using the Bonferroni correction test for 1 percent of confidence level ${ }^{4}$, while 21 (61.7 percent) without using this correction. The proposed typology seems to be appropriate for differences in economic productiveity and performance of public sectors among other significant variables such as GDP per capita or life expectancy. Variables with no significant differences among types of public sectors are related to taxes and savings, unemployment rates or growth of spending.

Table 3 presents the results for 29 R\&D related-variables. In this case, at 1 percent of confidence level, the relative number of significant variables is similar than in the overall and public sector performance variables: 16 (55.2 percent). However, the number of significant variables at 1 percent after the Bonferroni correction is larger: 8 variables (27.6 percent) related to governmental expenditures in $\mathrm{R} \& \mathrm{D}$, total business expenditure, researchers per employment and government expenditures in high education.

The main aim of this paper is to analyze the actual differences in R\&D performance and systems across European countries according to the structure and model of public sector which characterized each one. Do R\&D patterns in EU countries differ according to public sector typologies? In order to answer this, the statistical signifycance of the differences among the five public sector clusters explained before was assessed using ANOVAs. It seems to be clear that intensity of the R\&D investment (as a percentage of GDP) and business sector R\&D expenditures (as a percentage of GDP) actually differs among groups. Nordic or Scandinavian countries present the highest ratios of gross and private sector $\mathrm{R} \& \mathrm{D}$, followed by Continental or Western and Anglo-Saxon ones. On the other hand, Eastern and Southern or Mediterranean group invest a lower proportion of their GDP in R\&D activities. Nevertheless, these differences are smoothing when public sector R\&D is analyzed. Even more, in the case of government $R \& D$ and $R \& D$ financed by the government the differences are not significant, while the differences on the rest of variables related to $\mathrm{R} \& \mathrm{D}$ are.

Figure 2 presents the main results. It shows the patterns of each model of public sector in EU countries about four key variables within the innovation system (top graph of the figure)-gross R\&D investment, Public R\&D investment, R\&D performed in public sector, and R\&D services (Nace. 73). Eastern and Southern countries present higher ratios between public and private R\&D. Public sector $R \& D$ in these countries represent a higher proportion of the total of R\&D investment. Another key variable of $R \& D$ activities, $R \& D$ services (Nace. 73) does not differ significantly among groups.

${ }^{4}$ If confidence level, after Bonferroni test, is 5 percent, there are 12 significant variables ( 35.3 percents).
Similar results conclude if public sector performance (middle graph of Figure 2) and general economic indicators (bottom graph of Figure 2) are analyzed. Again, Nordic, Continental and, specially, Anglo-Saxon countries behaves better than Eastern and Mediterranean ones. Differences observed in terms of R\&D patterns, appear in terms of public sector and overall performance indicators. Those countries with more developed innovation systems are those with better numbers in terms of public sector efficiency and economic performance. At first sight, differences observed would seem to respond to income and wealth differences, and not to public sector model differences. However, following the ANOVA results, this doubt is refuted.

Although differences among groups in terms of GDP per capita follow the same path than previously analyzed differences on $R \& D$ and public sector performance, the rank of each cluster differs. In terms of income per capita, Anglo-Saxon countries leads, followed by Nordic and Continental countries and Southern or Mediterranean ones behaves clearly better than Eastern economies. This ranking slightly changes when focusing $R \& D$ patterns. Thus, Nordic countries, such as Sweden or Finland, achieve R\&D numbers higher than expected, while Anglo-Saxon and, specially, Mediterranean countries worsen related to expected ranking according to economic position. To sum up, diversity of public sector models in EU countries plays a key role both in terms of R\&D patterns and public sector performance and efficiency. Not only economic differences are significant, but differences on the way structuring and administering $R \& D$ activities among these five clustering groups are observed in European countries at this time.

\section{Results: Testing Disparities within Public Sector's Typologies}

Though this suggests that our conclusions are plausible, there is a need to take a more self-critical view in some related aspects. Firstly, some authors ask to what extent is there really an Anglo-Saxon model. The United States and the United Kingdom are very different in many ways, and have different trends, so one could turn this around and suggest that the United Kingdom is far more like France, while United States is far more like Switzerland. Secondly, the current Germany system is now under radical changes, so its belonging to a narrow cluster can be discussed ${ }^{5}$. Finally, some authors (see, for example, Frenken, 2003 [32]) suggest that national boundaries are being broken down and a pan-European system is instead taking its place, not only in terms of convergence due to

\footnotetext{
${ }^{5}$ For example, there is no such thing as the Rhineland model in Germany, but a changing German traditional system over time (Schweiger, 2004 [33]).
} 


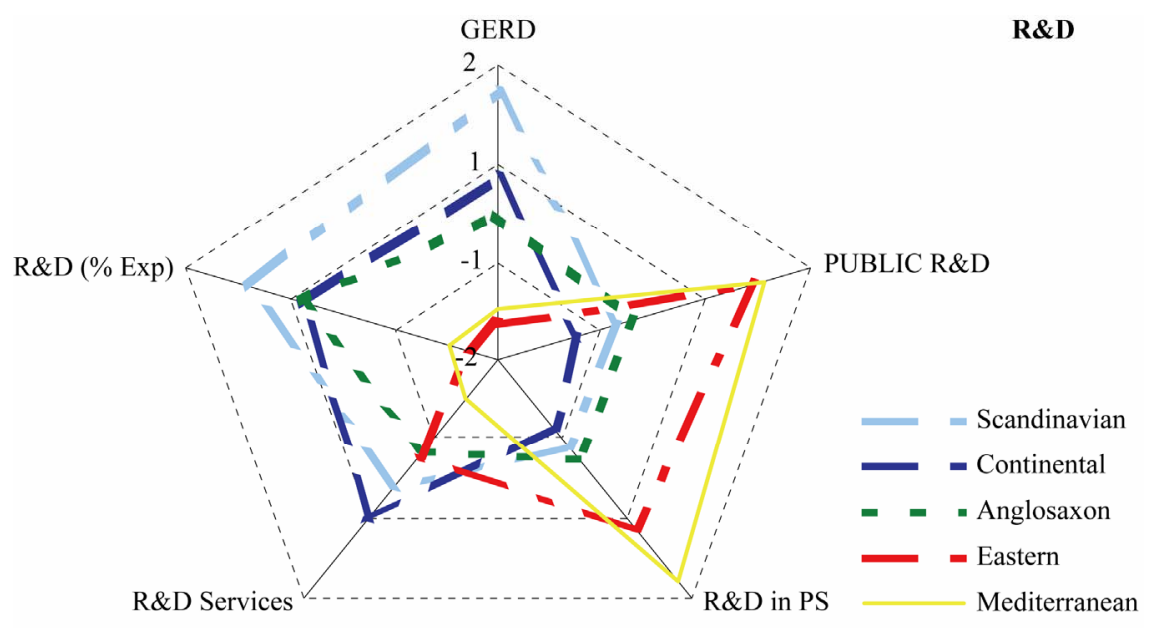

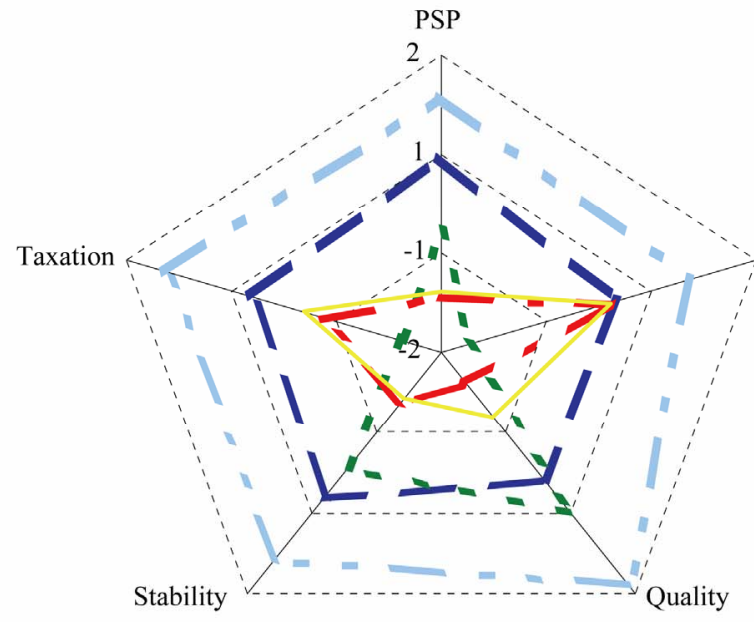

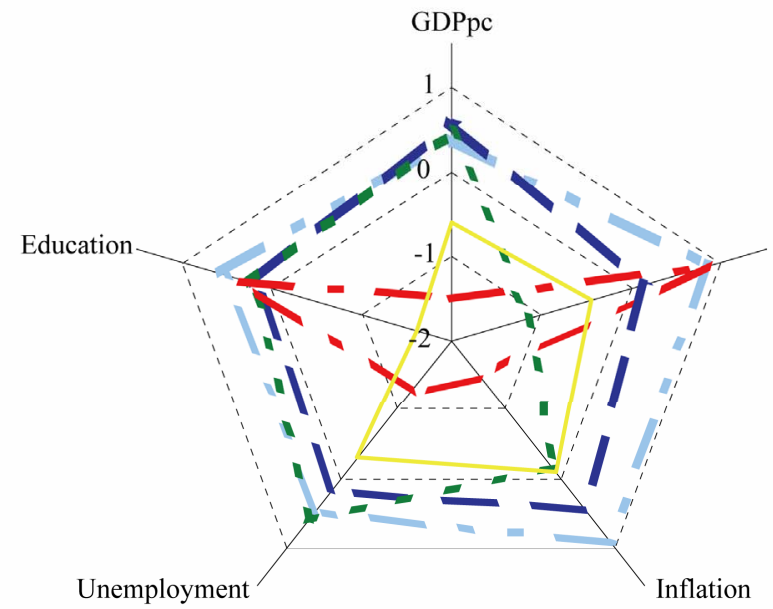

PS
Expenditures

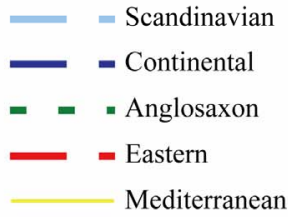

GENERAL Inequality

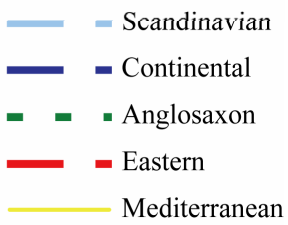

Figure 2. Structure, performance and innovation in public sector in Europe and US (normalized variables).

fiscal constraints imposed by the Euro stability pact. These critics could make the adopted typology here differ, but, in any case, it is the more extended one in the literature.

To cope with the intra-typology disparities, the idea of whether the differences between each cluster are greater than the differences within each typology is sought to be confirmed. For such a confirmation, Pearson variation coefficients have been used. Firstly, they have been estimated among the five groups and, later, within each one. 
Table 3. ANOVA results for $R \& D$ variables.

\begin{tabular}{|c|c|c|c|c|}
\hline & $\mathbf{N}$ & Variation coefficient & $\mathbf{F}$ & $\mathbf{p}$ \\
\hline R\&D/Total & 25 & 0.46 & $9.40^{\mathrm{c}}$ & $0.0002^{\mathrm{c}}$ \\
\hline GERD & 25 & 0.48 & $13.40^{\mathrm{c}}$ & $0.0000^{\mathrm{c}}$ \\
\hline GERD per capita & 25 & 0.58 & $20.03^{c}$ & $0.0000^{\mathrm{c}}$ \\
\hline \% GERD financed by Government & 25 & 0.35 & $8.11^{\mathrm{b}}$ & $0.0004^{\mathrm{b}}$ \\
\hline GERD financed by Government & 24 & 0.38 & 3.74 & 0.0208 \\
\hline BERD (\% GERD) & 25 & 0.26 & $6.23^{\mathrm{a}}$ & $0.0020^{\mathrm{a}}$ \\
\hline \% BERD financed by Government & 25 & 0.74 & 3.10 & 0.0386 \\
\hline BERD & 25 & 0.61 & $11.58^{\mathrm{c}}$ & $0.0000^{\mathrm{c}}$ \\
\hline GOVERD (\% GERD) & 25 & 0.62 & $11.41^{\mathrm{c}}$ & $0.0000^{\mathrm{c}}$ \\
\hline GOVERD & 25 & 0.55 & 1.34 & 0.2882 \\
\hline HERD & 25 & 0.48 & $5.87^{\mathrm{a}}$ & $0.0027^{\mathrm{a}}$ \\
\hline HERD (\% GERD) & 25 & 0.37 & 3.49 & 0.0255 \\
\hline PUBLIC R\&D (\% GERD) & 25 & 0.37 & $5.99^{\mathrm{a}}$ & $0.0024^{\mathrm{a}}$ \\
\hline PUBLIC R\&D & 25 & 0.40 & $5.05^{\mathrm{a}}$ & $0.0055^{\mathrm{a}}$ \\
\hline Ratio Public-Private (\% GERD) & 25 & 0.74 & $5.36^{\mathrm{a}}$ & $0.0042^{\mathrm{a}}$ \\
\hline Ratio Public-Private & 25 & 0.78 & 4.01 & 0.0149 \\
\hline GBOARD & 24 & 0.36 & 2.97 & 0.0457 \\
\hline GBOARD (defence) & 22 & 1.55 & 0.88 & 0.4932 \\
\hline Total researchers & 25 & 2.37 & 1.30 & 0.3019 \\
\hline Researchers per 1000 employment & 24 & 0.47 & $10.12^{\mathrm{c}}$ & $0.0001^{\mathrm{c}}$ \\
\hline$R \& D$ researchers per 1000 employment & 22 & 0.42 & $12.40^{\mathrm{c}}$ & $0.0000^{\mathrm{c}}$ \\
\hline Triadic patents & 25 & 2.50 & 1.08 & 0.3920 \\
\hline EPO patents & 25 & 2.04 & 1.07 & 0.3952 \\
\hline Average patents & 25 & 2.16 & 1.06 & 0.3982 \\
\hline \%GERD in Business sector & 25 & 0.24 & $5.42^{\mathrm{a}}$ & $0.0039^{\mathrm{a}}$ \\
\hline \%GERD in Higher education & 24 & 0.53 & $7.37^{\mathrm{c}}$ & $0.0009^{c}$ \\
\hline \%GERD in Government & 24 & 0.35 & 4.08 & 0.0148 \\
\hline \%GERD in Public Sector & 25 & 0.36 & $5.27^{\mathrm{a}}$ & $0.0045^{\mathrm{a}}$ \\
\hline GVA R\&D Services & 23 & 0.90 & 2.19 & 0.1113 \\
\hline Employment R\&D Services & 23 & 0.83 & 1.94 & 0.1468 \\
\hline
\end{tabular}

${ }^{\mathrm{a}}$ Variables significant at $1 \%$; ${ }^{\mathrm{b}}$ Variables significant at Bonferroni coefficient $(\alpha=0.05)$; and ${ }^{\mathrm{c}}$ Variables significant at Bonferroni coefficient $(\alpha=0.01)$.

Then, between the various pair wise combinations of individual countries belonging to each cluster, aiming to confirm that there are inter-typologies and intra-typologies differences. Our research hypothesis is that each typology maintains a kind of heterogeneous behavior, and nothing objects that the differences within each group are in some cases larger than the differences among groups, although the idea that the differences among these five public sector typologies are irrelevant cannot be derived from the previous assertion.

Figure 3 displays the disparities (measured as Pearson variation coefficients) within each type of public sector 
face to the disparities among the 5 types. The AngloSaxon type is the only one for which differences both in general items and in R\&D indicators are larger than those among the 5 types. The continental model is more homogeneous in general public sector and economic items but diversity in R\&D indicators is larger. In the Mediterranean, Eastern and Nordic models, the intra-heterogeneity is less noticeable than the inter-types one. The Nordic type, in particular, is the most homogeneous type within the five clusters identified in the previous sections.

Concerning the balance between overall indicators and R\&D indicators, Figure 4 shows how intra-type variations in $R \& D$ are much larger than inter-types ones than in economic or public sector performance indicators, where inter-types differences are more outstanding.

\section{Concluding Remarks}

The debate of the role of the public sector has shifted in these years towards empirical assessments of the efficiency and usefulness of its activities. Economic theory and empirical researches have shown that innovation and, concretely, R\&D achieve better economic performance at aggregate level. Focusing on public sector, the results on

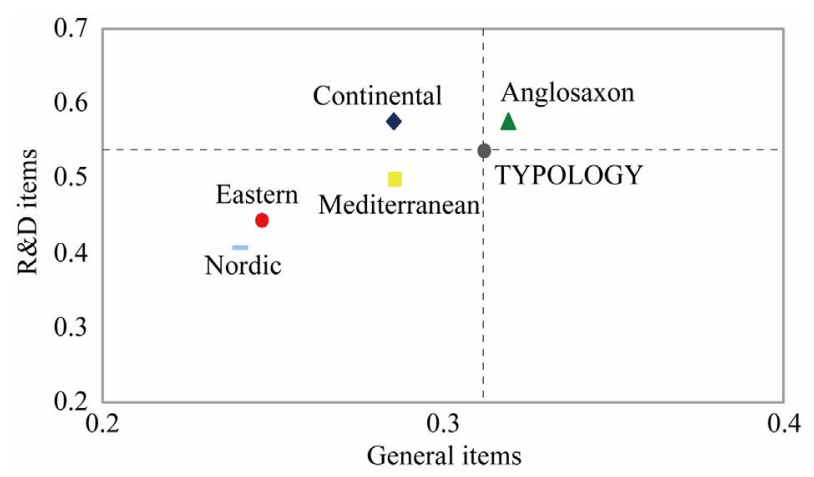

Figure 3. Variation coefficients within and between public sector-typologies.

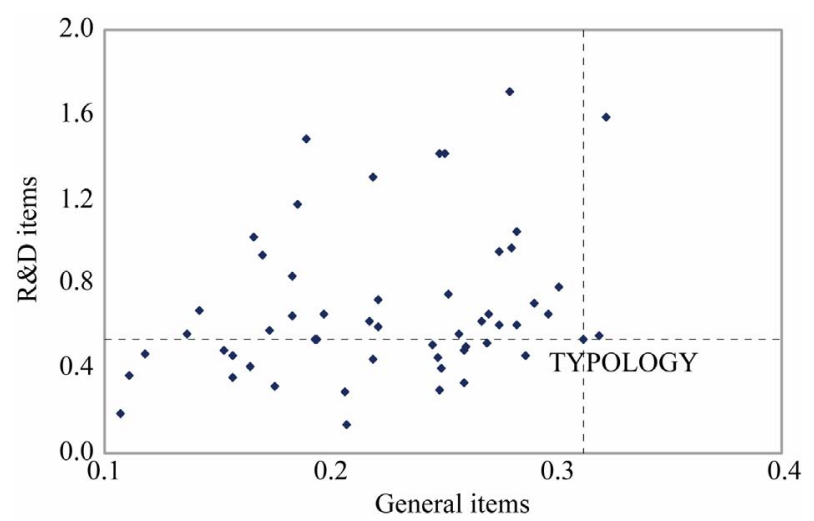

Figure 4. Percentage of variables for which differences among countries are higher than among country-typologies. this paper show that this relationship persists. R\&D behaves a key dimension within performance and efficiency of public administrations. Those countries with higher R\&D are those with better performance of their public sector activities. Gross R\&D and private sector R\&D have a longer effect on the public sector performance, while public R\&D has importance as supporting and stimulating innovation and research within private firms.

The second main research hypothesis of this paper asked for the influence of diversity of public sector models in the European countries. Different ways of structuring and administering public activities across the EU should lead to different ways to performing R\&D systems. It seems to be clear that countries with higher R\&D, such as Scandinavian and Continental countries, are those with better public performance show, while Mediterranean and Eastern countries present a worse performance in public administrations and lower general R\&D figures. This pattern also can be observed if R\&D services are analyzed. Continental and Scandinavian countries are those with a more developed $R \& D$ services sector, although Eastern economies show a high relative development in these kinds of tertiary activities. On the other hand, variables related to public sector R\&D play the opposite role. Thus, Mediterranean and Eastern countries present the highest values in public R\&D (as a percentage of total $R \& D$ ) and $R \& D$ performed within the public administrations, while those countries with higher general R\&D spending, such as Scandinavian and Continental ones, present lower values in these two variables.

A certain complementary but asymmetric role between public and private $R \& D$ can be suggested since those countries leading both types of R\&D develop much more business R\&D than those countries lagging behind. Public and private R\&D deem to be considered as initially complementary but, once a certain level is obtained, countries with a high public sector performance develop much more private $R \& D$ than public $R \& D$. This result suggests that a key dimension of the public sector performance should be the capacity of transmitting public R\&D efforts in private investments: the capacity of spreading the public funding in economic system and innovation. Further research is needed to complement this type of results with innovation indicators: R\&D is just an input where the returns into innovative products, process or organizational changes do not necessarily to be the same in all countries.

\section{REFERENCES}

[1] K. Arrow, "Economic Welfare and the Allocation of Resources for Inventions,” In: R. Nelson, Ed., The Rate and Direction of Invective Activity, Princeton University Press, New York, 1962, pp. 609-625. 
[2] R. Griffith, "How Important is Business R\&D for Economic Growth and Should the Government Subsidise It?" Institute of Fiscal Studies Briefing Notes, Vol. 12, London, 2000.

[3] Organization for Economic Co-operation and Development, "Science, Technology and Industry Outlook," OECD, Paris, 2002,

[4] D. Mowery and B. Sampat, "Universities and Innovation,” In: J. Fagerberg, D. Mowery and R. Nelson, Eds., The Handbook of Innovation, Edward Elgar, London, 2002, pp. 266-290.

[5] European Commission, "European Competitiveness Report 2004,” Brussels, 2005.

[6] A. Maroto and L. Rubalcaba, "Structure, Size and Reform of the Public Sector in Europe,” In: P. Koch and P. Windrum, Eds., Innovation in Public Sector, Management, Creativity and Entrepreneurship, Edward Elgar, London, 2008, pp. 41-63.

[7] US Council on Competitiveness, "Public Sector Innovation,” National Innovation Initiative Working Group Report, US Council on Competitiveness, 2005.

[8] Z. Griliches, "The Search for R\&D Spillovers," Scandinavian Journal of Economics, Vol. 94, 1992, pp. 29-47. doi:10.2307/3440244

[9] P. David, B. Hall and A. Toole, "Is Public R\&D a Complement or Substitute for Private R\&D? A Review of the Econometric Evidence," Research Policy, Vol. 29, No. 4-5, 2000, pp. 497-529. doi:10.1016/S0048-7333(99)00087-6

[10] G. Esping-Andersen, "The Three Worlds of Welfare Capitalism,” Polity Press, Cambridge, 1990.

[11] R. Titmuss, “Social Policy,” Allen and Unwin, London, 1974.

[12] SCP/CERP, "Public Sector Performance. An International Comparison of Education, Health Care, Law and Order and Public Administration," Social and Cultural Planning Office, The Hague, 2004.

[13] F. Castles, "Welfare State Development in Southern Europe,” West European Politics, Vol. 18, No. 2, 1995, pp. 291-313. doi:10.1080/01402389508425073

[14] M. Rodhes, “Southern European Welfares States,” Frank Cass, London, 1997.

[15] G. Hofstede, “Culture's Consequences. International Differences in Work-related Values,” Sage, California, 1980.

[16] V. Mamadouh, "National Political Cultures in the European Union,” In: M. Thompson, G. Grendstad and P. Selle, Eds., Cultural Theory as Political Science, Routledge, London, 1999, pp. 138-153.

[17] J. Loughlin, "Nation, State and Region in Western Europe,” In: L. Bekemans, Ed., Culture: Building Stone for Europe 2002, Reflections and Perspectives, Peter Lang Publishing, Brussels, 1994, pp. 90-111.

[18] L. Hooghe, "The European Commission and the Integration of Europe. Images of Governance," Cambridge University Press, Cambridge, 2002. doi:10.1017/CBO9780511491979

[19] E. Page, “Administering Europe,” In: E. Page and E.
Hayward, Eds., Governing the New Europe, Polity Press, Cambridge, 1995, pp. 257-285.

[20] M. Mellens, "Determinants of Demographic Behaviour," In: J. de Beer and L. Van Wissen, Eds., Europe: One Continent, Different Worlds, European Population Scenarios for the 21st Century, Dordrecht, 1999, pp. 5-32.

[21] C. Hood, “A Public Management for All Seasons,” Public Administration, Vol. 69, No. 1, 1991, pp. 3-19. doi:10.1111/j.1467-9299.1991.tb00779.x

[22] H. G. Frederickson, "Comparing the Reinventing Government Movement with the New Public Administration," Public Administration Review, Vol. 56, No. 3, 1996, pp. 263-270. doi:10.2307/976450

[23] C. Pollit and G. Bouckaert, "Public Management Reform. A Comparative Analysis," Oxford University Press, Oxford, 2004.

[24] C. Knox, "Public Service Reform. Northern Ireland Executive,” Review of Public Administration Briefing Paper, Vol. 26, 2002.

[25] R. Premfors, "Reshaping the Democratic State: Swedish Experiences in a Comparative Perspective," Public Administration, Vol. 76, No. 1, 1998, pp. 141-159. doi:10.1111/1467-9299.00094

[26] L. Torres and V. Pina, "Reshaping Public Administration: The Spanish Experience Compared to UK,” Public Administration, Vol. 82, No. 2, 2004, pp. 445-464. doi:10.1111/j.0033-3298.2004.00402.x

[27] G. Capano, “Administrative Traditions and Policy Change. When Policy Paradigms Matter: The Case of Italian Administrative Reform during the 90s," Public Administration, Vol. 81, No. 4, 2003, pp. 781-801. doi:10.1111/j.0033-3298.2003.00371.x

[28] G. Henry and K. C. Dickey, "Implementing Performance Monitoring: A Research and Development Approach," Public Administration Review, Vol. 53, No. 3, 1993, pp. 203-213. doi: $10.2307 / 3110124$

[29] C. Pope, G. Robert, P. Bate and J. Le May, "Lost in Translation: A Multilevel Case Study of the Metamorphosis of Meanings and Action in Public Sector Organizational Innovation,” Public Administration, Vol. 84, No. 1, 2006, pp. 59-79. doi:10.1111/j.0033-3298.2006.00493.x

[30] P. Koch and P. Windrum, "Innovation in Public Sector. Management, Creativity and Entrepreneurship,” Edward Elgar, London, 2008.

[31] R. Walker, E. Jeanes and R. Rowlands, "Measuring Innovation: Applying the Literature-Based Innovation Output Indicator to Public Services,” Public Administration, Vol. 80, No. 1, 2002, pp. 201-214. doi:10.1111/1467-9299.00300

[32] K. Frenken, "Why Is Economic Geography Not an Evolutionary Science?” Proceedings of the EAEPE Conference, University of Maastricht, Maastricht, 7 November 2003, 27 Pages.

[33] C. Schweiger, "The Reform of the German Economy. The Agenda 2010 and Beyond,” Proceedings of the 54th Annual PSA conference, University of Lincoln, Lincoln, 7 April 2004, 24 Pages. 